ICRDET-2021, February 26-27, 2021, AICE, Jaipur, India

International Journal of Technical Research \& Science (Special Issue) ISSN No.:2454-2024 (online)

\title{
NON-TOXIC GREEN CORROSION INHIBITORS- A REVIEW
}

\author{
Sanjana Chugh and Susmita Sharma \\ Anand International College of Engineering, Jaipur, Rajasthan, India
}

\begin{abstract}
This review article summarizes the research work done on the use of natural compounds as non-toxic green corrosion inhibitors.Corrosion control of metals is very important. Natural extract have been widely used to protect the metal from corrosion. The use of inhibitors is one of the best options of protecting metals and alloys against corrosion. Plant extracts are environmentally friendly, inexpensive, readily available and also renewable. Development of green chemistry and green chemical technologies offers novel synthetic methods for ionic liquids, which are considered as new corrosion green inhibitors.
\end{abstract}

\section{INTRODUCTION}

Corrosion is the destruction and deterioration of metals as a result of reaction with environment ${ }^{1}$ (Fontana and Greene 1987). It is slow but spontaneous process.Corrosion can cause disastrous damage to metal and alloy structures causing economic consequences in terms of repair, replacement, product losses, safety and environmental pollution. Due to these harmful effects, corrosion is an undesirable phenomenon that ought to be prevented.To protect metals or alloys from corrosion, approaches such as isolating the structure from aggressive media (using coatings or film-forming chemicals) or compensating for the loss of electrons (corrosion is an oxidation process) from the corroded structure (e.g. cathodic protection by impressed current or by using active sacrificial anodes) are employed. From 1960's onward, a large number of synthetic organic compounds have been studied as anticorrosive materials in which heteroatoms such as $\mathrm{C}, \mathrm{N}, \mathrm{O}$, and $\mathrm{S}$ were identified to be the prime reason for its corrosion inhibition ability.However, most of these inhibitors were expensive, harmful to humankind, and nonbiodegradable ${ }^{2}$. So,more attention was given towards the development of naturally derived environmentally benign organic corrosion inhibitors. Apparently, every plant contains several active phytochemicals, and they are the ideal to replace traditional toxic inhibitors ${ }^{3}$. In this review article we discuss some plant extract as corrosion inhibitors for steel and aluminium.

\section{PLANT EXTRACTS AS CORROSION INHIBITOR FOR STEEL}

Plants and their part have been used by human beings for their basic needs such as production of food-stuffs, shelters, clothing, fertilizers, flavors and fragrances, medicines and also as corrosion inhibitors. The use of natural products as corrosion inhibitors can be traced back to the 1930's when plant extracts of Chelidonium majus (Celandine) and other plants were used for the first time in $\mathrm{H}_{2} \mathrm{SO}_{4}$ pickling baths (Sanyal, 1981). After then, interest in using natural products as corrosion inhibitors increased.

M.S. Al-Otaibi etal4, in 2014 reported the corrosion inhibitive effect of eight plants namely Lycium shawii (L.S.), Teucrium oliverianum (T.O.),Ochradenus baccatus(O.B.),Anvillea garcinii(A.G.), Cassia italica (C.I.), Artemisia sieberi (A.S.), Carthamus tinctorius (C.T.) and Tripleurospermum auriculatum (T.A.) grown in Saudi Arabia. They evaluate corrosion inhibition of these plants on mild steel in $0.5 \mathrm{M} \mathrm{HCl}$ solution using Open Circuit Potential(OCP),Tafel plots and Electrochemical Impedance Spectroscopy (EIS) methods.

A comparative study was done by M. Shyamala and P. K. Kasthuri in $2011^{5}$ on the inhibitory effects of plant extracts, Ocimum sanctum, Aegle marmelos, and Solanum trilobatum, on the corrosion of mild steel in $1 \mathrm{~N} \mathrm{HCl}$ medium using weightloss method, electrochemical methods, and hydrogen permeation method. On comparison, it was found that the maximum inhibition was shown by Ocimum sanctum with $99.6 \%$ inhibition efficiency at $6.0 \% \mathrm{v} / \mathrm{v}$ concentration of the extract

Anjali Peter etal ${ }^{6}$ studied the anticorrosive efficacy of Guar Gum with mild steel in acidic medium. Gums have been found to be good corrosion inhibitors due to their functional group; they form complexes with metal ions and on the metal surfaces. Most gums have - $\mathrm{COOH}$ functional groups, which can increase the contribution of electron or charge transfer and hence facilitate inhibition through adsorption. According to Ayssar et al. ${ }^{7}$ (2010), the aqueous neem leaves extract was found to be an excellent potential corrosion inhibitor for carbon steel in $1.0 \mathrm{M} \mathrm{HCl}$.

Rocha et al. ${ }^{8}$ observed the combined effect of mango and orange peel extracts for corrosion inhibition on carbon steel in the acidic medium over a concentration range of 200-600 ppm. They concluded that polar heterosides and hydroxyl groups are the leading cause of inhibition property. Anticorrosive property6 of Mangifera indica L. Leaf Extract was studied for the prevention of commercial steel in $3.5 \mathrm{wt} \% \mathrm{NaCl}$ environment. Corrosion prevention occurs by forming an insoluble organometallic complex between metal ions and functional groups in the antioxidants at the metal-electrolyte interface..Corrosion prevention occurs by forming an insoluble organometallic complex between metal ions and functional groups in the antioxidants at the metal-electrolyte interface.

Saleh and his co-workers ${ }^{9}$ performed an exhaustive work with Opuntia ficus indica, as a steel corrosion inhibitor. The aqueous extract of the inhibitor is found as a cathodic-type which is get absorbed over the electrode surface in physical nature and follows unimolecular Langmuir adsorption. They were also studied with aloe vera leaves and 
ICRDET-2021, February 26-27, 2021, AICE, Jaipur, India

International Journal of Technical Research \& Science (Special Issue) ISSN No.:2454-2024 (online)

fruits peels of mango, orange and pomegranate fruits on the corrosion of $\mathrm{MS}, \mathrm{Al}, \mathrm{Zn}$ and $\mathrm{Cu}$ in both $\mathrm{HCl}$ and $\mathrm{H}_{2} \mathrm{SO}_{4}$ acid solutions.

Sangeetha et al.2012 ${ }^{10}$ Banana peel extract (constituent of this extract is bananadine (3Z,7Z,10Z)-1-oxa-6azacyclododeca-3,7,10-triene) was reported as a good corrosion inhibitor with $\mathrm{Zn}$ in distilled water for carbon steel corrosion by the weight loss, thermometric , FTIR, and AFM analysis. Obtained results show that percentage inhibition efficiency first decrease with the addition of $\mathrm{Zn}$ but after increasing $\mathrm{Zn}$ concentration it increased.

Gupta and Jain in $2014^{11}$ reported the Corrosion inhibition by Aloe barbadensis (aloe vera) extract as green inhibitor for mild steel in $\mathrm{HNO}_{3}$.Aloe vera plant belongs to the family of Liliacea.The constituents of gel are polysaccharides, glycoproteins, vitamins, mineral, and enzymes. Obtained results show its synergistic type effect, and percentage inhibition efficiency was decrease with rise in temperature and increase with increasing extract concentration ${ }^{11}$.

Desai et $\mathrm{al}^{12}$., reported Hibiscus rosa-sinensis leaves extract as a good corrosion inhibitor for mild steel in $\mathrm{HCl}$ medium by the use of weight loss and EIS techniques. Obtained results show that the percentage inhibition efficiency was increased with the increasing temperature and concentration and show mixed-type inhibitor effect, and adsorption process was spontaneous and followed the Langmuir, Flory-Huggins and Freundlich adsorption isotherms. 16

Noor $2007^{13}$ Extract of fenugreek leaves reported as a good inhibitor for mild steel in $\mathrm{HCl}$ and $\mathrm{H}_{2} \mathrm{SO}_{4}$ solution but more efficient in $\mathrm{HCl}$ solution. Inhibition efficiency was decrease with rise in temperature but increase with increasing inhibitor concentration in $\mathrm{HCl}$ while both temperature and concentration increased the inhibition efficiency for mild steel in $\mathrm{H}_{2} \mathrm{SO}_{4}$ solution. Langmuir adsorption isotherm followed in $\mathrm{HCl}$ medium and Temkin followed in $\mathrm{H}_{2} \mathrm{SO}_{4}$ medium.

Yamuna and Athony $2014^{14} 18 \mathrm{C}$. sinensis leaf extract reported as a corrosion inhibitor in aqueous medium by the use of weight loss, UV, and FT-IT methods. Obtained results show that inhibition efficiency increase with increasing inhibitor concentration but decrease with rise in temperature

Nwankwo ${ }^{15}$ and his coworkers studied the use of Amaranthus cordatus as the corrosion inhibitor for conventional mild steel in $0.5 \mathrm{M}$ and $1.0 \mathrm{M}$ of both $\mathrm{H} 2 \mathrm{SO} 4$ and $\mathrm{NaCl}$. The result showed that the rates of corrosion of the mild steel increased with an increase in concentration of the acid or base and also decreased with increasing volume of Amaranthus cordatus.

Norzila etal., studied the effect of Piper nigrum extract on corrosion of mild steel

Aluminium Corrosion:

Rehan in $2003^{16}$ reported that Phoenix dactylifera as a good corrosion inhibitor for $\mathrm{Al}$ in $\mathrm{NaOH}$ solution by weight loss and PDP method. His results showed that the inhibition efficiency increase with increasing temperature and concentration

Abd-El-Nabey et al ${ }^{17} 2012$ The extracts of Damsissa, Corchours oitorius reported as a good inhibitor for the corrosion of aluminum in aqueous sodium carbonate by the use of gasometry, potentiodynamic polarization, and electrochemical impedance spectroscopy (EIS).

Avwiri and Igho $2003^{18}$ Vernonia amygdalina reported as a fine corrosion inhibitor for aluminum in $\mathrm{HCl}$ and HNO3 medium by the use of weight loss method. But its inhibition performance was much better in $\mathrm{HNO}_{3}$ solution as compare to $\mathrm{HCl}$ medium.

Nnanna et al. $2012^{19}$ The inhibition effect of Newbouldia laevis leaves extract reported as a good inhibitor on the corrosion of aluminum $\mathrm{HCl}$ and $\mathrm{H}_{2} \mathrm{SO}_{4}$ solutions by the use of gravimetric technique. Obtained results show that $\mathrm{N}$. laevis inhibitor effect was more efficient in $\mathrm{HCl}$ than $\mathrm{H}_{2} \mathrm{SO}_{4}$.

Umoren et al. $2012^{20}$ Coconut coir dust extract reported as a good inhibitor for aluminum corrosion in $1 \mathrm{M} \mathrm{HCl}$ medium by the use of weight loss and hydrogen evolution method. It was exhibited that percentage IE efficiency increased with increasing temperature and concentration. Obtained results show the Langmuir adsorption performance.

\section{CONCLUSION}

The literature revealed that natural plant extracts are effective green corrosion inhibitors against various metals and alloys.Green inhibitors are excellent inhibitors under a variety of corrosive environments for most of the metals. This article has shown that the usage of such eco-friendly corrosion inhibitors is the only way onward in the search for safer and environmentally secure protection against metal corrosion. The non-toxicity and biodegradability are the major advantages for these inhibitors.

\section{REFERENCES}

[1] Buchweishaija, J. Phytochemicals as green corrosion inhibitors in various corrosive media. Tanz. J.Sci. 2009, 35, 77-92.

[2] Verma, C.; Ebenso, E. E.; Bahadur, I.; Quraishi, M. A. An overview on plant extracts as environmental sustainable and green corrosion inhibitors for metals and alloys in aggressive corrosive media. J. Mol. Liq. 2018, 266, 577- 590, DOI: 10.1016/j.molliq.2018.06.110.

[3] M.S.Al-OtaibiaA.M.Al-MayoufaM.KhanaA.A.MousaaS.A.Al-zroabH.Z.Alkhathlan, Arabian Journal of Chemistry, Volume 7, Issue 3, July 2014, Pages 340-346

DOI Number: https://doi.org/10.30780/specialissue-ICRDET-2021/008 
ICRDET-2021, February 26-27, 2021, AICE, Jaipur, India

International Journal of Technical Research \& Science (Special Issue) ISSN No.:2454-2024 (online)

[4] M. Shyamala, P. K. Kasthuri, "A Comparative Study of the Inhibitory Effect of the Extracts of Ocimum sanctum, Aegle marmelos, and Solanum trilobatum on the Corrosion of Mild Steel in Hydrochloric Acid Medium", International Journal of Corrosion, vol. 2011, Article ID 129647, 11 pages, 2011

[5] Anjali Peter, Sanjay K. Sharma \&Ime Bassey Obot, Journal of Analytical Science and Technology, volume 7, Article number: 26 (2016)

[6] Ayssar N, Ideisan AA, Ibrahim AR, Maysoon A-K (2010) UAE neem extract as a corrosion inhibitor for carbon steel in $\mathrm{HCl}$ solution. International Journal of Corrosion 2010:1-9.

[7] Da Rocha, J. C.; Gomes, J. A. d. C. P.; D’Elia, E. Aqueous Extracts of Mango and Orange Peel as Green Inhibitors for Carbon Steel in Hydrochloric Acid Solution. Mater. Res. 2014, 17, 1581- 1587, DOI: 10.1590/1516-1439.285014.

[8] R. M. Saleh, A. A. Ismail and A. H. El-Hosary, Br. Corros. J., 17, 131 (1982)

[9] Sangeetha M, Rajendran S, Sathiyabama J, Prabhakar P (2012) Eco friendly extract of banana peel as corrosion inhibitor for carbon steel in sea water. J Nat Prod Plant Resour 2(5):601-610.

[10] Gupta P, Jain G (2014) Corrosion inhibition by Aloe barbadensis (aloe vera) extract as green inhibitor for mild steel in HNO3. IJSRR 3(4):72-83.

[11] Desai PS (2015b) Azadirachta indica (neem) leaf extract used as corrosion inhibitors for mild steel in hydrochloric acid. GE-International Journal of Engineering Research 3(1):8-23

[12] Noor EA (2007) Temperature effects on the corrosion inhibition of mild steel in acidic solutions by aqueous extract of fenugreek leaves. International Journal of Electrochemical Science 2:996-1017

[13] Yamuna J, Athony N (2014) Citrus sinensis L. leaf extract as an efficient green corrosion inhibitor for mild steel in aqueous medium. International Journal of ChemTech Research 7(01):37-43

[14] M. O. Nwankwo, P. O. Offor, S. I. Neife, L. C. Oshionwu, and N. E. Idenyi, "Amaranthus cordatus as a green corrosion inhibitor for mild steel in $\mathrm{H}_{2} \mathrm{SO}_{4}$ and $\mathrm{NaCl}$," Journal of Minerals and Materials Characterization and Engineering, vol. 2, no. 3, pp. 194-199, 2014

[15] Rehan HH (2003) Corrosion control by water-soluble extracts from leaves of economic plants. Materialwissenschaft und Werkstofftechnik 34(2):232-237

[16] Abd-El-Nabey BA, Abdel-Gaber AM, Elawady GY, El-Houssein S (2012) Inhibitive action of some plant extracts on the alkaline corrosion of aluminum. Int J Electrochem Sci 7:7823-7839

[17] Avwiri O, Igho OF (2003) Inhibitive action of Vernonia amygdalina on the corrosion of aluminium alloys in acidic media. Material Letter 57:3705-3711.

[18] Nnanna LA, Obasi VU, Nwadiuko OC, Mejeh KI, Ekekwe ND, Udensi SC (2012) Inhibition by Newbouldia laevis leaf extract of the corrosion of aluminium in $\mathrm{HCl}$ and $\mathrm{H} 2 \mathrm{SO} 4$ solutions. Archives of Applied Science Research 4(1):207-217

[19] Umoren S, Obot IB , Gasem Z, Odewunmi NA. Experimental and theoretical studies of red apple fruit extract as green corrosion inhibitor for mild steel in $\mathrm{HCl}$ solution. Journal of Dispersion Science and Technology (justaccepted). 2014.

[20] M. O. Nwankwo, P. O. Offor, S. I. Neife, L. C. Oshionwu, and N. E. Idenyi, "Amaranthus cordatus as a green corrosion inhibitor for mild steel in $\mathrm{H} 2 \mathrm{SO} 4$ and $\mathrm{NaCl}$," Journal of Minerals and Materials Characterization and Engineering, vol. 2, no. 3, pp. 194-199, 2014

[21] N. Mohd and A. S. Ishak, "Thermodynamic study of corrosion inhibition of mild steel in corrosive medium by Piper nigrum extract," Indian Journal of Science and Technology, vol. 8, no. 17, Article ID 63478, pp. 1-7, 2015.

[22] Corrosion is the destruction and deterioration of metals as a result of reaction with environment (Fontana and Greene 1987) "Fontana MG, Greene ND. Corrosion Engineer. 1987". 